\title{
Japan science head in move to limit decision-making role of officials
}

Tokyo. Makiko Tanaka, the outspoken politician who heads Japan's Science and Technology Agency (STA), has sent shock waves through the government bureaucracy in Tokyo by precipitating the dismissal of one of her agency's senior officials. The move stems from a dispute over the reform of semi-government research and development organizations affiliated with the agency.

At a cabinet meeting on 25 December, Tanaka complained that the secretary general of STA, Kinju Atarashi, was blocking her attempts to reveal the names of semigovernment organizations, called tokushu hojin, that she thinks need to be "reviewed".

Within barely 24 hours, and following a storm of protest from outraged cabinet members, Atarashi, who had been seconded from the Ministry of International Trade and Industry (MITI), was removed from his post and recalled to his former agency.

Atarashi is the first victim of efforts at reform by the cabinet of Prime Minister Tomiichi Murayama that could have an enormous impact on the structure of Japan's government-funded research.

In nearly four decades of unbroken rule by the Liberal Democratic Party (LDP), a cosy relationship had developed between the ruling party and the bureaucracy. Although an LDP member would head each ministry and agency, real decision-making and policy formulation were carried out by senior officials. In return, the officials helped the LDP to stay in power.

Now, reformist politicians such as Morihiro Hosokawa, who served as prime minister immediately after the LDP's fall, want to shift some of the administrative power from the bureaucracy to elected officials. Such moves are popular with the public, and Japan has entered what one leading MITI official describes as an "era of Kasumigaseki bashing".

Tokushu hojin have become the main focus of the Murayama administration's attack. There are 92 of these semi-government organizations run by the various ministries and agencies and they consume a large portion of the government's budget. Many implement or support government research and development.

STA, for example, has six: the National Space Development Agency (NASDA), the Institute of Physical and Chemical Research (RIKEN), the Atomic Energy Research Institute of Japan (JAERI), the Power Reactor and Nuclear Fuel Corporation (PNC), the Japan Information Center of Science and Technology (JICST) and the Research and Development Corporation of Japan (JRDC). These are responsible for most of the agen-

cy's spending on research and development. MITI has 13, including the New Energy and Industrial Technology Development Organization (NEDO) that administers nearly all the ministry's research and development projects. And the Ministry of Education, Science and Culture has eight, including the Japan Society for the Promotion of Science (JSPS), which runs many international and domestic programmes for universities.

Such bodies have come under criticism partly because they are havens for retiring bureaucrats under a process called amakudari or "coming down from heaven", whereby retired bureaucrats serve three or four years on a high salary as directors of semigovernment organizations they formerly administered. They then re-

\section{IMAGE UNAVAILABLE FOR COPYRIGHT REASONS} tire and receive a generous retirement allowance.

In the worst cases, some retired bureaucrats become "migratory birds" (watari dori), moving from one semi-government organization to another and collecting large retirement allowances on each departure.

Last September, representatives of the ruling coalition parties - namely the LDP, the Social Democratic Party (SDP) and Sakigake - outlined an ambitious programme of reform. They called for selected tokushu hojin to be either abolished, reduced in size, privatized, merged or transferred to local authorities. The politicians believe that such rationalization would make possible sufficient savings to finance a cut in income tax. All agencies and ministries have been asked to name tokushu hojin that they think need 'review'.

Not surprisingly, government officials have been extremely reluctant to do so, and no organization has yet been officially targeted. The officials are not only thinking of their own retirement; the present system gives them strong control of the tokushu hojin through 'old boy' networks, and these organizations account for a significant portion of government budgets, which they are loath to relinquish.

At the cabinet meeting on 25 December, Tanaka is said to have quoted Atarashi as telling her not to identify publicly any STA organizations targeted for reform because "government organizations in Kasumigaseki are public institutions, not personal properties of politicians". The matter might have ended there. But Hiromu Nonaka, the home affairs minister and one of the architects of the present coalition government, mentioned Tanaka's complaints at a press conference. The next day, Atarashi was asked to pack his bags and return to MITI.

Atarashi's summary dismissal has shocked government officials. "I could not believe it when I read it in the newspapers," says one of his colleagues, claiming that Atarashi was "too honest" and naive. "He was simply voicing the opinion of the vast majority of bureaucrats. But he made the mistake of saying it direct to Makiko Tanaka."

Tanaka is popular with the public because of her plain speaking and forthright views. She is the daughter of the late Kakuei Tanaka, a powerful politician who resigned as prime minister in the mid-1970s over a bribes scandal involving the Lockheed Tristar, but who continued to rule Japan's political world for many more years until he had a stroke.

But Tanaka does not get on well with STA officials. For example, late last year she complained bitterly about the terms of a US-Japan agreement allowing Japanese astronauts to fly in US space programmes only to find that her senior officials had failed to explain fully to her the terms of the agreement.

Tanaka has not revealed which tokushu hojin she would like to see reformed. But her repeated criticisms of the space organization NASDA, which accounts for about a quarter of the agency’s $¥ 600$-billion (US\$6billion) annual budget, suggests it may be a possible target.

The reform of tokushu hojin is popular with the public and politicians. But it could be very damaging for Japan's government research enterprise if not carried out carefully. Part of the success of RIKEN, for example, one of Japan's most successful government research institutes, stems from its tokushu hojin status that gives it more flexibility and autonomy than other government research institutes.

All government agencies and ministries have to submit proposals naming specific tokushu hojin by 10 February. Officials appear to have been hoping that the whole thing would blow over with vague promises of reform. But politicians have, through the Atarashi incident, brought the issue to the fore in the public's eye. And it has become a cornerstone of the Murayama administration's fight to remain in power.

David Swinbanks 